ElementerIs: Jurnal Ilmiah Pendidikan Dasar Islam

Volume 2 Nomor 1 Mei 2020

e-ISSN: 2655-6324

\title{
SEQUENTIAL EXPLORATORY: PEMBELAJARAN SENI TARI BAGI CALON GURU MADRASAH IBTIDAIYAH DI MASA PANDEMI COVID-19
}

\author{
Mutiara Sari Dewi \\ Universitas Islam Malang \\ e-mail: mutiara.sari@unisma.ac.id
}

Diterima: 19 Juni 2020 | Direvisi: 29 Juni 2020 | Disetujui: 1 Juli 2020 (C) 2020 Pendidikan Guru Madrasah Ibtidaiyah Fakultas Agama Islam Universitas Islam Malang

\begin{abstract}
Abstrak
This study aims to analyze: 1) the learning conditions of dance during the Covid 19 pandemic; and 2) media, learning methods, and learning resources used in learning dance for prospective Madrasah Ibtidaiyah teachers during the pandemic Covid 19. Learning dance for prospective Madarasah Ibtidaiyah teachers was chosen as the theme and / or part of the research variable based on the consideration that it has complex problems during the Covid Pandemic period 19. This research is a mixed method research with sequential exploratory research type. The research subjects consisted of 34 prospective Madrasah Ibtidaiyah teachers who were taking dance education courses at the Madrasah Ibtidaiyah Teacher Education Study Program, Islamic University of Malang. Data collection techniques are done through indirect interviews (personal chat, email, and Google form) and documentation (video dance assignments). The results showed that: 1) Only 31\% of prospective teachers feel the effectiveness of dance learning. 2) Online learning media (tools) in the form of whatsapp applications, a combination of question and answer methods, discussions, lectures and hands-on practice, and YouTube as a reference source chosen and declared effective in learning dance during the Covid 19 pandemic.
\end{abstract}

Keyword: learning dance, teacher candidates, MI, covid 19

\begin{abstract}
Abstrak
Penelitian ini bertujuan untuk menganalisis: 1) kondisi pembelajaran tari selama pandemi Covid 19; dan 2) media, metode pembelajaran, dan sumber belajar yang digunakan dalam pembelajaran tari untuk calon guru Madrasah Ibtidaiyah selama pandemi Covid 19. Belajar tari untuk calon guru Madarasah Ibtidaiyah dipilih sebagai tema dan / atau bagian dari variabel penelitian berdasarkan pertimbangan bahwa ia memiliki masalah yang kompleks selama periode pandemi Covid 19.

This work is licensed under Creative Commons Attribution Non Commercial 4.0 International License Available online on: http://riset.unisma.ac.id/index.php/je
\end{abstract}


Penelitian ini adalah penelitian metode campuran dengan jenis penelitian sequential exploratory. Subjek penelitian terdiri dari 34 calon guru Madrasah Ibtidaiyah yang mengambil kursus pendidikan tari di Program Studi Pendidikan Guru Madrasah Ibtidaiyah, Universitas Islam Malang. Teknik pengumpulan data dilakukan melalui wawancara tidak langsung (obrolan pribadi, email, dan formulir Google) dan dokumentasi (tugas tarian video). Hasil penelitian menunjukkan bahwa: 1) Hanya 31\% calon guru merasakan efektifitas belajar menari. 2) Media pembelajaran online dalam bentuk aplikasi whatsapp, kombinasi metode tanya jawab, diskusi, ceramah dan praktik langsung, dan YouTube sebagai sumber rujukan yang dipilih dan dinyatakan efektif dalam belajar menari selama pandemi Covid 19.

Kata kunci: belajar tari, calon guru, MI, covid 19

\section{Pendahuluan}

Pembelajaran seni tari bagi calon guru Madrasah Ibtidaiyah (MI) atau setara dengan Sekolah Dasar (SD) merupakan sebuah keharusan. Hal tersebut tidak lepas dari kebutuhan setiap guru MI harus memiliki bekal kemampuan menguasi materi yang diajarkan di MI, salah satunya yaitu seni tari (Arisyanto et al., 2019). Seni tari merupakan bagian dari pendidikan seni yang membantu terbentuknya karakter siswa sesuai dengan yang tertera pada tujuan pendidikan nasional (Komalasari, 2001). Pendidikan seni di SD tidak lepas dari peran guru dalam mengajarkan setiap materi sesuai dengan tujuan pembelajaran dan tentunya mudah diterapkan oleh siswa (Retnoningsih, 2017). Oleh karena itu, setiap calon guru MI wajib memiliki bekal untuk mampu mengajarkan seni, khususnya seni tari kepada siswanya sesuai dengan kapasitas pembelajaran seni.

Hal itu tentu akan lebih mudah tercapai apabila pembelajaran selama perkuliahan oleh calon guru terlaksana sesuai dengan Rencana Pembelajaran Semester (RPS) yang telah disepakati antara dosen mata kuliah seni tari dengan calon guru MI. Pembelajaran seni tari yang pada dasarnya terdiri dari 30\% materi dan 70\% praktek (Russell-Bowie, 2013) sangat membutuhkan pertemuan tatap muka antara dosen dan calon guru MI sebagai mahasiswa. Permasalahan pembelajaran seni tari di perkuliahan dalam beberapa waktu terakhir menjadi lebih komplek. Bukan hanya dari kondisi latar belakang calon guru yang 90\% tidak memiliki dasar-dasar kemampuan menari (Russell-Bowie, 2013) tetapi juga didudukung kondisi perkuliahan yang tetap berjalan melalui jaringan online (Daring) selama masa pandemic Covid 19 (Zhafira et al., 2020).

Saat ini seluruh dunia sedang menghadapi masa pandemic Covid 19 yang disebabkan oleh virus Corona. Kasus Covid 19 pertama kali ada di Indonesia pada bulan Maret 2020, diumumkan oleh Presiden Joko Widodo di Istana Kepresidenan 
(Ihsanuddin, 2020). Adanya konferensi pers tersebut sekaligus menjadi pintu gerbang perubahan pendidikan di Indonesia yang berjalan hingga saat ini. Semua jenjang pendidikan mulai dari tingkat pendidikan anak usia dini (RA/BA/TA/KB/TPA), Sekolah Dasar, Sekolah Menengah Pertama, Sekolah Menengah Atas, hingga Perguruan Tinggi wajib menerapkan sistem pembelajaran daring atau jaringan online.

Pada mulanya hanya 2 minggu pertama dan terdapat beberapa sekolah yang masih memberlakukan pembelajaran offline atau tatap muka secara langsung. Namun, seiring berjalannya waktu, berdasarkan data Cnn/ysp (2020) menunjukkan bahwa hanya 2,4\% lembaga dari seluruh lembaga pendidikan di Indonesia yang menyelenggarakan pembelajaran tatap muka dikarenakan tidak memiliki perangkat pendukung dan daerahnya tidak terjangkit pandemic Covid 19. Brasmati (2020) mengungkapkan bahwa Presiden Republik Indonesia, Joko Widodo, akan memperpanjang pembelajaran dengan sistem daring hingga akhir tahun 2020. Kondisi tersebut tentu sangat mempengaruhi rencana perkuliahan, pendekatan, model, strategi, metode, media, dan sarana pembelajaran yang digunakan pendidik (Nurkholis, 2021). Pembelajaran seni tari bagi calon guru Madrasah Ibtidaiyah juga tak luput dari perubahan ini. Apapun kondisi lingkungan saat ini, pembelajaran harus tetap dilaksanakan. Pendidik harus mampu menjalankan perannya dengan professional dan mampu mengadapi segala tantangan seiring bergantinya jaman (Dewi, 2017) .

Tugas pendidik calon guru menjadi sangat komplek untuk merancang ulang pembelajaran yang nyaman dan tentunya mampu dipahami oleh semua calon guru. Sebuah hal yang menarik untuk dikaji dan dianalisis, mengingat pembelajaran tari merupakan pembelajaran yang didominasi dengan kegiatan praktek. Berdasarkan analisis tersebut, maka tujuan dari penelitian ini yaitu menganalisis: 1) kondisi pembelajaran seni tari saat pandemic Covid 19; dan 2) media, metode pembelajaran, dan sumber belajar yang digunakan dalam pembelajaran seni tari dimasa pandemic Covid 19.

\section{Metode}

Penelitian ini merupakan penelitian mix method dengan jenis penelitian sequential exploratory. Creswell W. John (2011) mengungkapkan bahwa sequential exploratory digunakan dengan tujuan mengungkapkan fakta berdasarkan data penelitian dan teori yang ada melalui analisis secara kualitatif dan didukung dengan analisis kuantitatif. Fokus dari penelitian ini yaitu mendeskripsikan hasil penelitian terkait pembelajaran seni tari bagi calon guru Madrasah Ibtidaiyah di 
masa pandemi Covid 19. Subyek penelitian terdiri dari 34 calon guru Madrasah Ibtidaiyah yang sedang menempuh mata kuliah pendidikan seni tari di Program Studi Pendidikan Guru Madrasah Ibtidaiyah Universitas Islam Malang. Sebanyak 2 (6\%) calon guru yang memiliki latar belakang sebagai penari diluar jam perkuliahan, sedangkan 32 (94\%) lainnya tidak memiliki latar belakang sebagai penari.

Dalam mengidentifikasi pelaksanaan pembelajaran seni tari pada masa pandemic Covid 19, peneliti menggunakan instrument penelitian berupa instrument wawancara dan survey melalui google form. Dalam form tersebut terdapat 19 ragam pertanyaan. Adapun indicator pertanyaan yang digunakan sebagai berikut.

Tabel 1. Indikator Pertanyaan Survey Pelaksanaan Pembelajaran Seni Tari di Masa Pandemi Covid 19.

\begin{tabular}{|c|c|c|}
\hline No & Indikator Pertanyaan & Jenis Jawaban \\
\hline 1 & $\begin{array}{l}\text { Tingkat kenyamanan mahasiswa } \\
\text { pelaksanaan pembelajaran seni tari melalui } \\
\text { Daring (selama masa pandemi Covid 19) }\end{array}$ & $\begin{array}{l}\text { Skala (4 tingkatan skala } \\
\text { likert) }\end{array}$ \\
\hline 2 & $\begin{array}{l}\text { Tingkat keefektifan pembelajaran seni tari } \\
\text { melalui Daring (selama masa pandemi Covid 19) }\end{array}$ & $\begin{array}{l}\text { Skala (4 tingkatan skala } \\
\text { likert) }\end{array}$ \\
\hline 3 & $\begin{array}{l}\text { Sarana pembelajaran yang efektif dan nyaman } \\
\text { digunakan dalam pelaksanaan pembelajaran seni } \\
\text { tari melalui Daring (selama masa pandemi Covid } \\
\text { 19) }\end{array}$ & $\begin{array}{l}\text { Pilihan ganda (whatsapp, } \\
\text { google meet, google } \\
\text { classroom, edmodo, } \\
\text { zoom, lainya) }\end{array}$ \\
\hline 4 & $\begin{array}{l}\text { Perbandingan tingkat kenyamanan dalam } \\
\text { pelaksanaan pembelajaran seni tari sebelum dan } \\
\text { selama masa pandemic Covid } 19\end{array}$ & $\begin{array}{l}\text { Pilihan ganda (sebelum, } \\
\text { sesudah masa pandemic } \\
\text { Covid 19) }\end{array}$ \\
\hline 5 & $\begin{array}{l}\text { Sumber belajar yang paling sering digunakan } \\
\text { dalam pelaksanaan pembelajaran seni tari } \\
\text { (selama masa pandemi Covid 19) }\end{array}$ & $\begin{array}{l}\text { Pilihan ganda } \text { (e-book, } \\
\text { buku cetak, youtube, } \\
\text { instagram, facebook, } \\
\text { lainnya) }\end{array}$ \\
\hline 6 & $\begin{array}{l}\text { Metode pembelajaran seni tari yang efektif } \\
\text { digunakan sebelum masa pandemic Covid } 19\end{array}$ & $\begin{array}{l}\text { Pilihan ganda (tanya } \\
\text { jawab, diskusi, ceramah, } \\
\text { praktik langsung, } 3 \text { dari } \\
\text { 4, semuanya efektif) }\end{array}$ \\
\hline 7 & $\begin{array}{l}\text { Metode pembelajaran seni tari yang efektif } \\
\text { digunakan selama masa pandemic Covid } 19\end{array}$ & $\begin{array}{l}\text { Pilihan ganda (tanya } \\
\text { jawab, diskusi, ceramah, } \\
\text { praktik langsung, } 3 \text { dari } \\
\text { 4, semuanya efektif) }\end{array}$ \\
\hline 8 & Kesulitan yang dihadapi calon guru dalam & Deskripsi \\
\hline
\end{tabular}




\begin{tabular}{|c|c|c|}
\hline No & Indikator Pertanyaan & Jenis Jawaban \\
\hline & $\begin{array}{l}\text { pembelajaran seni tari sebelum masa pandemic } \\
\text { Covid } 19\end{array}$ & \\
\hline 9 & $\begin{array}{l}\text { Kesulitan yang dihadapi calon guru dalam } \\
\text { pembelajaran seni tari selama masa pandemic } \\
\text { Covid } 19\end{array}$ & Deskripsi \\
\hline 10 & $\begin{array}{l}\text { Harapan calon guru pada pelaksanaan } \\
\text { pembelajaran seni tari selama masa pandemic } \\
\text { Covid } 19\end{array}$ & Deskripsi \\
\hline
\end{tabular}

Teknik pengumpulan data dilakukan melalui wawancara tidak langsung (personal chatt, email, dan google form) dan dokumentasi (video tugas tari). Teknis analisis data secara kuantitatif menggunakan penghitungan mean dan prosentase dari setiap jawaban yang diberikan oleh subyek penelitian.

\section{Hasil dan Pembahasan}

Dalam penelitian ini, sesuai dengan tujuan dan pendekatan penelitian, maka hasil penelitian dipaparkan menjadi 2 pendekatan, yaitu secara kualitatif dan kuantitatif. Setiap poin memaparkan data penelitian sesuai dengan tujuan penelitian, yaitu: 1) menganalisis kondisi pembelajaran seni tari saat pandemic Covid 19; dan 2) menganalisis media, metode pembelajaran, dan sumber belajar yang digunakan dalam pembelajaran seni tari dimasa pandemic Covid 19.

\section{Data Kualitatif}

\section{Kondisi Pembelajaran Seni Tari Saat Pandemic Covid 19.}

Data kualitatif diperoleh dari wawancara secara tidak langsung dengan subyek penelitian. Subyek penelitian yang menjawab sesuai dengan indikator tingkat kenyamanan mahasiswa dalam pelaksanaan pembelajaran seni tari melalui Daring (selama masa pandemi Covid 19)ini sejumlah 34 responden, jadi 100\% responden menjawab dengan tepat. Adapun dua jawaban yang mewakili jawaban 34 responden sebagai berikut.

Pembelajaran seni tari selama masa pandemi ini, tetap merasa sangat nyaman. (nfa)

Saya merasa sangat tidak nyaman, karena pembelajaran seni tari bukan untuk diangan-angan saja, tetapi harus praktik setiap geraknya. (imj)

Indikator pertanyaan yg kedua yaitu tentang tingkat keefektifan pembelajaran seni tari melalui Daring (selama masa pandemi Covid 19). Sebanyak 
$100 \%$ responden memberikan jawaban yang sesuai dengan indikator pertanyaan. Adapun dua jawaban yang mewakili jawaban 34 responden sebagai berikut.

Menurut saya sudah efektif, karena gangguan pembelajaran online bagi saya bukan pada proses pembelajaran tapi dari hal pendukung yaitu sinyal internet. (jaw)

Sangat tidak efektif, karena menurut saya, pembelajaran seni tari lebih efektif jika kita bisa praktik langsung dengan teman. (asm)

Calon guru dengan inisial nama asm, pembelajaran seni tari selama masa pandemic Covid 19 sangat tidak efektif, karena pembelajaran seni tari lebih efektif jika kita bisa praktik langsung dengan teman (asm). Hal ini senada dengan pendapat Russell-Bowie (2013) bahwa pembelajaran seni tari lebih efektif jika diberikan melalui praktek langsung. Calon guru dengan inisial nama (jaw) menyatakan bahwa pembelajaran sudah efektif, namun tetap terdapat gangguan pembelajaran dalam hal pendukung pembelajaran yaitu sinyal internet. Penelitian yang sejalan dengan pernyataan tersebut menyatakan bahwa beberapa hal yang menghambat pembelajaran online yaitu keterbatasan sarana (Park \& Yun, 2018), salah satunya sinyal internet yang belum cukup memadai.

Pertanyaan ketiga yang diberikan saat wawancara, sesuai dengan indikator pertanyaan perbandingan tingkat kenyamanan dalam pelaksanaan pembelajaran seni tari sebelum dan selama masa pandemic Covid 19. Sama halnya dengan indikator pertanyaan pertama dan kedua, sebanyak 34 responden menjawab pertanyaan sesuai konteks indikator pertanyaan. Adapun satu jawaban yang mewakili jawaban 34 responden sebagai berikut.

Sangat nyaman sebelum masa pandemic Covid 19, karena kita bisa belajar secara langsung, tidak melalui daring (ipi).

Kesulitan yang dihadapi calon guru dalam pembelajaran seni tari sebelum masa pandemic Covid 19 sebagai salah satu indikator pertanyaan dalam wawancara penelitian ini. Sebanyak 100\% responden mampu menjawab pertanyaan sesuai dengan konteks indikator pertanyaan. Adapun satu jawaban yang mewakili jawaban 34 responden sebagai berikut.

Saya rasa tidak ada karena ketika pembelajaran dengan cara tatap muka bisa di tanyakan langsung sehingga lebih enak (mhn)

Berbeda dengan indikator pertanyaan terkait pembelajaran seni tari sebelum masa pandemic Covid 19, indikator pertanyaan tentang pembelajaran 
seni tari sebelum masa pandemic Covid 19, terdapat 1 responden yang tidak menjawab dengan tepat. Hanya ada 33 responden yang menjawab sesuai dengan konteks indikator pertanyaan. Adapun satu jawaban yang mewakili jawaban 34 responden sebagai berikut.

Komunikasi menjadi lebih terbatas, kesulitan saat pratek karena komunikasi hanya lewat wa saja jadi tidak bisa melihat secara langsung (msf)

Indokator pertanyaan yang terakhir terkait kondisi pembelajaran seni tari yaitu harapan calon guru pada pelaksanaan pembelajaran seni tari selama masa. Semua responden tentu mampu menjawab pertanyaan sesuai dengan konteks indikator pertanyaan. Adapun satu jawaban yang mewakili jawaban 34 responden sebagai berikut.

Semoga wabah Covid 19 cepet berlalu supaya bisa melakukan pembelajaran dikelas lagi (rhn)

\section{Media, Metode Pembelajaran, dan Sumber Belajar yang Digunakan Dalam Pembelajaran Seni Tari Dimasa Pandemic Covid 19.}

Media, metode pembelajaran, dan sumber belajar yang digunakan dalam pembelajaran seni tari dimasa pandemic Covid 19 tentu berbeda dengan sebelum masa pandemic saat pembelajaran masih berlangsung secara offline. Hal tersebut diketahui berdasarkan hasil analisis wawancara tidak langsung yang dilakukan dengan menggunakan 4 (empat) indikator yaitu: 1) sarana pembelajaran yang efektif dan nyaman digunakan dalam pelaksanaan pembelajaran seni tari melalui Daring (selama masa pandemi Covid 19). 2) sumber belajar yang paling sering digunakan dalam pelaksanaan pembelajaran seni tari (selama masa pandemi Covid 19). 3) metode pembelajaran seni tari yang efektif digunakan sebelum masa pandemic Covid 19. 4) metode pembelajaran seni tari yang efektif digunakan selama masa pandemic Covid 19.

Hampir semua responden menjawab sesuai dengan konteks indikator pertanyaan. Salah satu responden tidak menjawab pertanyaan dengan tepat hanya pada indikator pertanyaan pertama. Satu jawaban yang mewakili indikator terkait sarana pembelajaran yang efektif dan nyaman digunakan dalam pelaksanaan pembelajaran seni tari melalui Daring (selama masa pandemi Covid 19) sebagai berikut. 
Paling nyaman dan sesuai dengan sinyal di daerah teman-teman semua ya memang whatsapp, walau sebenarnya pembelajaran tari setidaknya lebih enak menggunakan zoom atau google meet (aki)

Dalam hal media (sarana) pembelajaran, berdasarkan hasil wawancara tidak langsung sebagian besar menggungkan whatsapp sebagai platform atau aplikasi yang paling mudah dan nyaman digunakan. Jawaban (aki) menunjukkan bahwa setiap media (sarana) pembelajaran pasti memiliki keterbatasan. Hal itu senada dengan pendapat Saripuddin et al. (2014) bahwa sekalipun media (sarana) tersebut dianggap nyaman, namun tetap memiliki keterbatasan sebagai media (sarana) dalam pembelajaran seni tari. Indikator kedua yaitu terkait sumber belajar yang paling sering digunakan dalam pelaksanaan pembelajaran seni tari (selama masa pandemi Covid 19). Adapun satu jawaban yang mewakili jawaban 34 responden sebagai berikut.

Youtube, walau paketan cepat habis, dan dirumah saya susah sinyal, tapi itu yang paling nyaman digunakan untuk melihat tutorial tari (rwh)

Sebagian besar menyatakan youtube sebagai sumber rujukan yang mudah bagi calon guru untuk melihat dan belajar secara langsung gerakan seni tari. Penggunaan youtube sebagai sumber rujukan tidak terlalu berbeda antara sebelum masa pandemic Covid 19 dengan selama masa pandemic. Penelitian yang dilakukan oleh (Priyanto, 2011) bahwa salah satu media e-learning yang dapat digunakan sebagai sumber rujukan pembelajaran seni tari yaitu youtube. Perbedaan yang cukup siginifikan justru tampak pada penggunaan metode pembelajaran yang dirasa efektif dan nyaman bagi calon guru sebelum masa pandemic dan selama masa pandemic Covid 19. Adapun satu jawaban yang mewakili jawaban 34 responden sebagai berikut.

Praktik langsung, karena saya kan tidak bisa menari, jadi lebih baik praktik langsung (rza)

Sebelum masa pandemic Covid 19, sebagian besar calon guru menyatakan bahwa metode praktik langsung menjadi satu-satunya metode yang dirasa efektif untuk pembelajaran seni tari. Hal tersebut juga tidak lepas dari latar belakang calon guru yang sebagian besar bukan seorang penari professional, bahkan ada yang belum pernah menari sekalipun. Permasalahan semakin komplek selama 
masa pandemic Covid 19, ketika 90\% calon guru tidak memiliki latar belakang menari (Russell-Bowie, 2013), dan pembelajaran tidak dilakukan secara langsung, sehingga pendidik calon guru sangat terbatas dalam memberikan contoh setiap gerakan tari. Jawaban dari indikator pertanyaan keempat yaitu tentang metode pembelajaran seni tari yang efektif digunakan selama masa pandemic Covid 19, semakin memperkuat data penelitian pembelajaran seni tari. Adapun satu jawaban yang mewakili jawaban 34 responden sebagai berikut.

Tanya jawab, diskusi, ceramah, praktik langsung, kombinasi metode tersebut, walaupun saya lebih senang mendengarkan suara dari pada membaca tulisan di layar hape (rba)

Berdasarkan data penelitian menunjukkan, sebagian besar calon guru lebih memilih metode pembelajaran kombinasi dari metode tanya jawab, diskusi, ceramah, praktik langsung sebagai metode yang cukup efektif untuk pembelajaran seni tari yang dilakukan selama masa pandemic Covid 19. Jawaban tersebut memiliki makna bahwa apapun kondisi pembelajaran seni tari, tetap membutuhkan metode praktik langsung.

\section{Data Kuantitatif}

\section{Kondisi Pembelajaran Seni Tari Saat Pandemic Covid 19.}

Hasil penelitian terkait kondisi pembelajaran seni tari sebelum dan saat Pandemic Covid 19 dibagi menjadi beberapa analisis, yaitu: 1) kenyamanan calon guru dalam pembelajaran seni tari selama masa Pandemic Covid 19; dan 2) keefektifan pembelajaran seni tari selama masa Pandemic Covid 19. Dalam hal kenyamanan calon guru dalam pembelajaran seni tari diperoleh data sebagai berikut.

Tabel 2. Tingkat Kenyamanan Calon Guru dalam Pembelajaran Seni Tari Selama Masa Pandemic Covid 19.

\begin{tabular}{llccc}
\hline No & Tingkat Kenyamanan & Jumlah & Mean & Prosentase \\
\hline 1 & Sangat nyaman & 2 & 0,06 & $6,0 \%$ \\
\hline 2 & Nyaman & 9 & 0,26 & $26 \%$ \\
\hline 3 & Cukup nyaman & 14 & 0,42 & $42 \%$ \\
\hline 4 & Tidak nyaman & 9 & 0,26 & $26 \%$ \\
\hline & Total & 34 & 100 & $100 \%$ \\
\hline
\end{tabular}


Tabel 3. Perbandingan Tingkat Kenyamanan Calon Guru dalam Pembelajaran Seni Tari Sebelum dan Selama Masa Pandemic Covid 19.

\begin{tabular}{clccc}
\hline No & \multicolumn{1}{c}{$\begin{array}{c}\text { Waktu Pembelajaran } \\
\text { Seni Tari }\end{array}$} & Jumlah & Mean & Prosentase \\
\hline 1 & $\begin{array}{l}\text { Lebih nyaman sebelum } \\
\text { masa pandemic Covid 19 }\end{array}$ & 29 & 0.85 & $85 \%$ \\
\hline 2 & $\begin{array}{l}\text { Lebih nyaman selama } \\
\text { masa pandemic Covid 19 } \\
\text { Total }\end{array}$ & 5 & 0.15 & $15 \%$ \\
\hline & 34 & 100 & $100 \%$ \\
\hline
\end{tabular}

Berdasarkan hasil penelitian tersebut secara umum tampak bahwa calon guru sebagian besar (68\%) merasa tidak nyaman dalam pembelajaran seni tari pada masa pandemic Covid 19. Bahkan 85\% menyatakan bahwa pembelajaran seni tari lebih nyaman dilaksanakan sebelum masa pandemic Covid 19. Hal tersebut tentu sejalan dengan pendapat (Nurkholis, 2021) bahwa pandemic Covid 19 sangat mempengaruhi kondisi pembelajaran termasuk tingkat kenyamanan peserta didik dalam pembelajaran. Data kondisi pembelajaran yang diperoleh dalam penelitian ini selain tingkat kenyamanan, yaitu tingkat keefektifan pembelajaran menurut persepsi calon guru Madrasah Ibtidaiyah. Data tersebut ditampilkan dalam tabel berikut:

Tabel 4. Tingkat Keefektifan Pembelajaran Seni Tari Pada Masa Pandemi Covid 19.

\begin{tabular}{|c|c|c|c|c|}
\hline No & $\begin{array}{c}\text { Waktu Pembelajaran Seni } \\
\text { Tari }\end{array}$ & Jumlah & Mean & Prosentase \\
\hline 1 & Sangat efektif & 3 & 0.09 & $9 \%$ \\
\hline 2 & Efektif & 4 & 0.12 & $12 \%$ \\
\hline 3 & Cukup efektif & 16 & 0.47 & $47 \%$ \\
\hline 4 & Tidak efektif & 11 & 0.32 & $32 \%$ \\
\hline & Total & 34 & 100 & $100 \%$ \\
\hline
\end{tabular}

Tabel 4 menunjukkan persepsi calon guru dalam tingkat keefektifan pembelajaran seni tari pada masa pandemic Covid 19 sebanyak 47\% menyatakan cukup efektif dan 32\% menyatakan tidak efektif. Hal tersebut berarti bahwa lebih dari 50\% calon guru tidak benar-benar merasakan keefektifan pembelajaran seni tari pada masa pandemic Covid 19. Hanya 31\% calon guru yang merasakan 
keefektifan pembelajaran seni tari. Hal ini tentu akan berdampak pada tercapainya tujuan dari pembelajaran seni tari. Lokasari Novian (2013) mengungkapkan bahwa pembelajaran seni tari dalam sebuah konteks pendidikan berfungsi untuk memberikan pengalaman, pengetahuan, dan pemahaman yang tidak hanya terbatas dalam hal teknik seni tari saja, melainkan juga pada keefektifan pembelajaran.

Media, Metode Pembelajaran, dan Sumber Belajar yang Digunakan Dalam Pembelajaran Seni Tari Dimasa Pandemic Covid 19.

Media pembelajaran yang digunakan yang digunakan dalam pembelajaran seni tari pada masa pandemic Covid 19 lebih difokuskan pada sarana pembelajaran dalam jaringan (Daring). Sarana tersebut terdiri dari: Whatsapp, Google Meet, Google Classroom, Edmodo, Zoom, lainnya. Tabel berikut menyajikan data hasi penelitian terkait sarana yang digunakan calon guru dalam pembelajaran seni tari.

Tabel 5. Media (sarana) yang Digunakan Calon Guru dalam Pembelajaran Seni Tari

\begin{tabular}{llccc}
\hline No & \multicolumn{1}{c}{ Media (sarana) } & $\begin{array}{c}\text { Jumlah } \\
\text { Pengguna }\end{array}$ & Mean & Presentase \\
\hline 1 & Whatsapp & 27 & 0.79 & $79 \%$ \\
\hline 2 & Google Meet & 4 & 0.12 & $12 \%$ \\
\hline 3 & Google Classroom & 0 & 0 & 0 \\
\hline 4 & Edmodo & 0 & 0 & 0 \\
\hline 5 & Zoom & 2 & 0.06 & $6 \%$ \\
\hline 6 & $\begin{array}{l}\text { Lainnya (media yang tidak } \\
\text { disebutkan dalam pilihan } \\
\text { tersebut) }\end{array}$ & 1 & 0.03 & $3 \%$ \\
\hline & & & $100 \%$ \\
\hline & Total & 34 & 100 & \\
\hline
\end{tabular}

Berdasarkan data hasil penelitian tersebut menunjukkan bahwa calon guru lebih banyak menggunakan media (sarana) pembelajaran daring berupa aplikasi whatsapp dalam pembelajarab seni tari selama masa pandemic Covid 19. Hal tersebut tampak dari sebanyak 79\% calon guru yang memilih jawaban whatsapp. Sisanya sebanyak 12\% menggunakan aplikasi google meet, 6\% menggunakan aplikasi zoom, 3\% tidak memilih semua jawaban (menggunakan aplikasi lain yang tidak dicantumkan dalam jawaban), serta $0 \%$ atau tidak ada sama sekali yang menggunakan edmodo dan google classroom. Media pembelajaran daring tersebut 
memang yang sering digunakan selama masa pandemi Covid 19 (Zhafira et al., 2020).

Dalam pembelajaran seni tari, pilihan aplikasi whatsapp sebagai sarana pembelajaran tentu memiliki banyak keterbatasan, terutama untuk kegiatan praktek cipta tari. Keterbatasan tersebut disebutkan oleh subyek penelitian melalui wawancara tidak langsung dan dianalisis melalui pendekatan kualitatif. Selain media (sarana) pembelajaran daring, metode pembelajaran merupakan poin penting dalam terlaksananya pembelajaran yang asik, nyaman, dan tentu dipahami oleh peserta didik. Adapun hasil penelitian terkait metode pembelajaran yang digunakan dijabarkan dalam tabel berikut:

Tabel 6. Metode Pembelajaran Digunakan dalam Pembelajaran Seni Tari

\begin{tabular}{llccc}
\hline No & Metode Pembelajaran & $\begin{array}{c}\text { Jumlah } \\
\text { Responden }\end{array}$ & Mean & Presentase \\
\hline 1 & Tanya jawab & 3 & 0.09 & $9 \%$ \\
\hline 2 & Diskusi & 1 & 0.03 & $3 \%$ \\
\hline 3 & Ceramah & 0 & 0 & 0 \\
\hline 4 & Praktik langsung & 3 & 0.09 & $9 \%$ \\
\hline 5 & $\begin{array}{l}\text { Tanya jawab, diskusi, } \\
\text { ceramah }\end{array}$ & 5 & 0.15 & $15 \%$ \\
\hline 6 & $\begin{array}{l}\text { Tanya jawab, diskusi, } \\
\text { ceramah, praktik langsung }\end{array}$ & 22 & 0.64 & $64 \%$ \\
\hline \multicolumn{2}{c}{ Total } & 34 & 100 & $100 \%$ \\
\hline
\end{tabular}

Tabel dan diagram tersebut menunjukkan bahwa metode yang paling sering digunakan dalam pembelajaran seni tari selama masa pandemic Covid 19 yaitu metode kombinasi antara metode tanya jawab, diskusi, ceramah, dan praktik langsung. Sebanyak 64\% calon guru memilih pilihan tersebut. Sebanyak 15\% juga memilih kombinasi antara metode pembelajaran tanya jawab, dikusi, dan ceramah. Metode pembelajaran tunggal dan atau mayoritas tampak kurang diminati untuk diterapkan dalam pembelajaran seni tari. Hal itu tampak dari sebanyak $9 \%$ yang memilih hanya menggunakan metode tanya jawab dan praktik langsung. Tentu hal tersebut selaras dengan kondisi pembelajaran seni tari yang lebih didominasi dengan kegiatan praktik (Russell-Bowie, 2013), walaupun dari hasil penelitian tersebut tidak bisa dianalisisi secara detail terkait berapa persen penggunaan metode praktek langsung. Hal menarik lainya yang bisa dikaji dari penelitian ini yaitu terkait sumber rujukan yang digunakan calon guru dalam pembelajaran seni tari selama masa pandemic Covid 19. 
Tabel 7. Sumber Rujukan Digunakan dalam Pembelajaran Seni Tari

\begin{tabular}{llccc}
\hline No & Sumber Rujukan & $\begin{array}{c}\text { Jumlah } \\
\text { Responden }\end{array}$ & Mean & Presentase \\
\hline 1 & E-Book & 3 & 0.09 & $9 \%$ \\
\hline 2 & Buku Cetak & 0 & 0 & 0 \\
\hline 3 & Youtube & 29 & 0.85 & $85 \%$ \\
\hline 4 & Instagram & 1 & 0.03 & $3 \%$ \\
\hline 5 & Facebook & 0 & 0 & 0 \\
\hline 6 & Lainnya & 1 & 0.03 & $3 \%$ \\
\hline & Total & 34 & 100 & $100 \%$ \\
\hline
\end{tabular}

Berdasarkan tabel dan diagram tersebut menunjukkan bahwa sebanyak 85\% calon guru menggunakan Youtube sebagai sumber rujukan pembelajaran seni tari selama masa pandemic Covid 19. Sebanyak 9\% menggunakan e-book. Hal ini tentu sangat wajar dan sesuai dengan konten pembelajaran seni tari yang lebih mudah dipelajari melalui video (Setiawan, 2013). Paparan data tersebut sekaligus menunjukkan bahwa pembelajaran seni tari bagi calon guru Madrasah Ibtidaiyah selama masa pandemi sebagian besar sangat berbeda dengan pembelajaran sebelum masa pandemic Covid 19.

\section{Simpulan}

Kondisi pembelajaran seni tari selama masa pandemic Covid 19 memiliki sisi negative dan positif. Sebagian besar (68\%) calon guru Madrasah Ibtidaiyah merasa tidak nyaman dalam pembelajaran seni tari pada masa pandemic Covid 19. Sebanyak 85\% menyatakan bahwa pembelajaran seni tari lebih nyaman dilaksanakan sebelum masa pandemic Covid 19. Hanya 31\% calon guru yang merasakan keefektifan pembelajaran seni tari.

Calon guru lebih banyak menggunakan media (sarana) pembelajaran daring berupa aplikasi whatsapp dalam pembelajarab seni tari selama masa pandemic Covid 19. Metode yang paling sering digunakan dalam pembelajaran seni tari selama masa pandemic Covid 19 yaitu metode kombinasi antara metode tanya jawab, diskusi, ceramah, dan praktik langsung. Sedangkan, sebanyak 85\% calon guru memilih youtube sebagai sumber rujukan utama dalam pembelajaran seni tari selama masa pandemic Covid 19.

Rekomendasi untuk penelitian selanjutnya, yaitu peneliti diharapkan mengambil sampel dengan jumlah yang lebih banyak dari penelitian ini. Fokus 
penelitian juga dapat ditambahkan variable lainnya yang dapat dijadikan variable moderator yaitu jenis kelamin dan self regulated learning.

\section{Daftar Rujukan}

Arisyanto, P., Untari, M. F. S., \& Sundari Riris Setyo. (2019). Penerapan Strategi Practice Rehearsal Pairs Pada Mata Kuliah Seni Tari dan Drama di UPGRIS. Refleksi Edukatika: Jurnal Ilmiah Kependidikan, 10(1), 1-9.

Brasmati. (2020). Tak Ingin Grusa-grusu, Jokowi Masih Godok Penerapan New Normal di Sektor Pendidikan. Tribunnews, 1-4. Tak Ingin Grusa-grusu, Jokowi Masih Godok Penerapan New Normal di Sektor Pendidikan

Cnn/ysp. (2020). Terbaru Dari Kemendikbud, Belajar di Rumah Akan Diperpanjang Hingga Akhir 2020. Liputan 6, 1. http://www.belajardirumah.org/2020/05/terbaru-dari-kemdikbud-belajardi-rumah.html

Creswell W. John. (2011). Educational Research: Planning, Conducting, and Evaluating Quantitative and Qualitative Research.

Dewi, M. S. (2017). Peran dan Tantangan Guru Raudhatul Atfhal Masa Kini. In F. Anita (Ed.), Pendidikan Islam Dalam Tantangan Globalisasi (1st ed., p. 117). Nirmana Media.

Ihsanuddin. (2020). Fakta Lengkap Kasus Corona di Indonesia. Kompas.Com, 1. https://nasional.kompas.com/read/2020/03/03/06314981/fakta-lengkapkasus-pertama-virus-corona-di-indonesia?page=all

Komalasari, H. (2001). Aplikasi model pembelajaran tari pendidikan di sdn nilem bandung.

Lokasari Novian Murti. (2013). Proses Pembelajaran Mahasiswa Seni Tari Pada. Universitas Negeri Makasar.

Nurkholis, M. (2021). Keefektivan Kebijakan E-Learning berbasis Sosial Media pada PAUD di Masa Pandemi Covid-19 Abstrak. Jurnal Obsesi: Jurnal Pendidikan Anak Usia Dini, 5(1), 212-228. https://doi.org/10.31004/obsesi.v5i1.535

Park, S., \& Yun, H. (2018). The Influence of Motivational Regulation Strategies on Online Students' Behavioral, Emotional, and Cognitive Engagement. American Journal of Distance Education, 32(1), 43-56. https://doi.org/10.1080/08923647.2018.1412738

Priyanto, W. P. (2011). Pengembangan Media E-Learning Pada Pembelajaran Seni 
Tari SMP Negeri di Kabupaten Sleman. http://staffnew.uny.ac.id/upload/131644621/penelitian/ringkasanpengenm-media-tari-di-smp.pdf

Retnoningsih, D. A. (2017). Eksistensi Konsep Seni Tari Tradisional Terhadap Pebentukan Karakter Siswa Sekolah Dasar. DIALEKTIKA Jurnal Pemikiran Dan Penelitian Pendidikan Dasar, 7(1), 20-29.

Russell-Bowie, D. E. (2013). What? Me? Teach dance? Background and confidence of primary preservice teachers in dance education across five countries. Research in Dance Education, 14(3), 216-232. https://doi.org/10.1080/14647893.2012.722614

Saripuddin, Haris, A., \& Nurhadi. (2014). Perancangan Aplikasi Media Pembelajaran Seni Budaya Berbasis Multimedia Pada Smp Db 1 Kota Jambi. Jurnal Ilmiah Media Processor, 9(1), 44-53.

Setiawan, A. (2013). Pemanfaatan Internet Sebagai Media Pembelajaran Seni Musik di SMP Negeri 2 Tonjong Kabupaten Brebes [Universitas Negeri Semarang]. https://lib.unnes.ac.id/19564/1/2503406007.pdf

Zhafira, N. H., Ertika, Y., \& Chairiyaton. (2020). Persepsi Mahasiswa Terhadap Perkuliahan Daring Sebagai Sarana Pembelajaran Selama Masa Karantina Covid-19. Jurnal Bisnis Dan Kajian Strategi Manajemen, 4(1), 37-45. 